\title{
Front Matter: Volume 8902
}

, "Front Matter: Volume 8902," Proc. SPIE 8902, Electron Technology Conference 2013, 890201 (25 July 2013); doi: 10.1117/12.2033989

SPIE. Event: Electron Technology Conference 2013, 2013, Ryn, Poland 


\title{
PROCEEDINGS OF SPIE
}

\section{Electron Technology Conference 2013}

\author{
Paweł Szczepański \\ Ryszard Kisiel \\ Ryszard S. Romaniuk \\ Editors
}

16-20 April 2013

Ryn, Poland

Organized by

Institute of Microelectronics and Optoelectronics, Warsaw University of Technology (Poland)

Conference Partner

CEZAMAT-Centre of Advanced Materials and Technologies (Poland)

Cooperating Organization and Publisher

SPIE 
The papers included in this volume were part of the technical conference cited on the cover and title page. Papers were selected and subject to review by the editors and conference program committee. Some conference presentations may not be available for publication. The papers published in these proceedings reflect the work and thoughts of the authors and are published herein as submitted. The publisher is not responsible for the validity of the information or for any outcomes resulting from reliance thereon.

Please use the following format to cite material from this book:

Author(s), "Title of Paper," in Electron Technology Conference 2013, edited by Paweł Szczepański, Ryszard Kisiel, Ryszard S. Romaniuk, Proceedings of SPIE Vol. 8902 (SPIE, Bellingham, WA, 2013) Article CID Number.

ISSN: 0277-786X

ISBN: 9780819495211

Published by

SPIE

P.O. Box 10, Bellingham, Washington 98227-0010 USA

Telephone +1 3606763290 (Pacific Time) · Fax +1 3606471445

SPIE.org

Copyright @ 2013, Society of Photo-Optical Instrumentation Engineers.

Copying of material in this book for internal or personal use, or for the internal or personal use of specific clients, beyond the fair use provisions granted by the U.S. Copyright Law is authorized by SPIE subject to payment of copying fees. The Transactional Reporting Service base fee for this volume is $\$ 18.00$ per article (or portion thereof), which should be paid directly to the Copyright Clearance Center (CCC), 222 Rosewood Drive, Danvers, MA 01923. Payment may also be made electronically through CCC Online at copyright.com. Other copying for republication, resale, advertising or promotion, or any form of systematic or multiple reproduction of any material in this book is prohibited except with permission in writing from the publisher. The CCC fee code is 0277-786X/13/\$18.00.

Printed in the United States of America.

Publication of record for individual papers is online in the SPIE Digital Library.

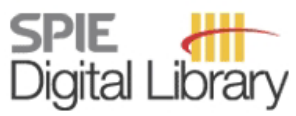

SPIEDigitalLibrary.org

Paper Numbering: Proceedings of SPIE follow an e-First publication model, with papers published first online and then in print and on CD-ROM. Papers are published as they are submitted and meet publication criteria. A unique, consistent, permanent citation identifier (CID) number is assigned to each article at the time of the first publication. Utilization of CIDs allows articles to be fully citable as soon as they are published online, and connects the same identifier to all online, print, and electronic versions of the publication. SPIE uses a six-digit CID article numbering system in which:

- The first four digits correspond to the SPIE volume number.

- The last two digits indicate publication order within the volume using a Base 36 numbering

system employing both numerals and letters. These two-number sets start with 00, 01, 02, 03, 04, $05,06,07,08,09,0 A, 0 B \ldots 0 Z$, followed by 10-1Z, 20-2Z, etc.

The CID Number appears on each page of the manuscript. The complete citation is used on the first page, and an abbreviated version on subsequent pages. Numbers in the index correspond to the last two digits of the six-digit CID Number. 


\title{
Contents
}

\author{
xiii Conference Committee \\ xvii Introduction
}

\section{PLENARY SESSION}

890202 Electron Technology - ELTE 2013 (Plenary Paper) [8902-138]

P. Szczepański, R. Kisiel, R. S. Romaniuk, Warsaw Univ. of Technology (Poland)

\section{SESSION 1 MICROELECTRONICS AND NANOELECTRONICS}

890203 Modern high power semiconductor devices (Invited Paper) [8902-122]

A. Napieralski, M. Napieralska, Ł. Starzak, M. Zubert, Lodz Univ. of Technology (Poland)

890204 ASICs in nanometer and 3D technologies for readout of hybrid pixel detectors [8902-127] P. Maj, P. Grybos, P. Kmon, R. Szczygiel, AGH Univ. of Science and Technology (Poland)

890205 Nanostructures in thin film opto-electronics (Invited Paper) [8902-109]

A. Kołodziej, AGH Univ. of Science and Technology (Poland); A. Jakubowski, Warsaw Univ. of Technology (Poland); M. Kołodziej, AGH Univ. of Science and Technology (Poland)

890206 The behavioral approach to silicon carbide power components modeling [8902-124] M. Zubert, A. Napieralski, M. Napieralska, G. Jabłoński, Ł. Starzak, M. Janicki, Lodz Univ. of Technology (Poland)

890207 Low noise charge pump (Invited Paper) [8902-2]

A. Grodzicki, W. A. Pleskacz, Warsaw Univ. of Technology (Poland)

890208 Miniature plasma jet for mass spectrometry [8902-4]

M. Babij, T. Gotszalk, Z. W. Kowalski, K. Nitsch, Wrocław Univ. of Technology (Poland);

J. Silberring, M. Smoluch, AGH Univ. of Science and Technology (Poland)

890209 The analysis of filling pulse parameters influence on ICTS data of GaAs MIS structures [8902-9]

Ł. Drewniak, S. Kochowski, Silesian Univ. of Technology (Poland); K. Nitsch, R. Paszkiewicz,

B. Paszkiewicz, Wrocław Univ. of Technology (Poland)

$89020 \mathrm{~A}$ Effective aluminum oxide thin films deposition using reactive pulsed magnetron sputtering: possibilities and limitations [8902-16]

M. Gruszka, W. Posadowski, Wrocław Univ. of Technology (Poland); Z. Sidor, A. Piotrowska, Institute of Electron Technology (Poland); A. Wiatrowski, Wrocław Univ. of Technology (Poland) 
8902 OB Selected properties of multi-terminal resistors embedded in printed circuit boards [8902-17] A. Kłossowicz, R. Kukuła, P. Winiarski, A. Dziedzic, Wrocław Univ. of Technology (Poland); W. Stęplewski, J. Borecki, Tele and Radio Research Institute (Poland)

8902 OC AC properties of low-pass RC filters embedded in printed circuit boards [8902-18] P. Winiarski, A. Kłossowicz, Wrocław Univ. of Technology (Poland); W. Stęplewski, J. Borecki, Tele and Radio Research Institute (Poland); K. Nitsch, A. Dziedzic, Wrocław Univ. of Technology (Poland)

8902 OD Instruction set extension for software defined radio in mobile GNSS applications [8902-19] K. Marcinek, W. A. Pleskacz, Warsaw Univ. of Technology (Poland)

$8902 \mathrm{OE} \quad$ Ultra-shallow fluorine and nitrogen implantation from r.f. plasma and its effect on electro-physical parameters of $\mathrm{Al} / \mathrm{HfO}_{2} / \mathrm{Si}$ MOS structures [8902-26] M. Kalisz, Warsaw Univ. of Technology (Poland) and Motor Transport Institute (Poland); R. Mroczyński, Warsaw Univ. of Technology (Poland); M. Szymańska, Warsaw Univ. of Technology (Poland) and Motor Transport Institute (Poland)

8902 OF Investigation of deep-level defects in InGaAsN/GaAs 3xQWs structures grown by AP-MOVPE [8902-35]

Ł. Gelczuk, M. Dąbrowska-Szata, P. Kamyczek, E. Płaczek-Popko, Wrocław Univ. of Technology (Poland); K. Kopalko, Institute of Physics (Poland); B. Ściana, D. Pucicki, D. Radziewicz, M. Tłaczała, Wrocław Univ. of Technology (Poland)

$89020 \mathrm{G}$ Microfabricated support structures for investigations of mechanical and electrical graphene properties [8902-40]

K. Gajewski, T. Gotszalk, Wrocław Univ. of Technology (Poland); A. Sierakowski, P. Janus,

P. Grabiec, Institute of Electron Technology (Poland)

$8902 \mathrm{OH}$ Influence of annealing temperature on electrical parameters and structure of Al contacts on p-type $4 \mathrm{H}$-SiC substrate [8902-47]

A. Kubiak, J. Rogowski, Ł. Ruta, Z. Lisik, Lodz Univ. of Technology (Poland)

8902 Ol Surface passivation of MSM photodetectors made on GaAsN epitaxial layers [8902-58] I. Zborowska-Lindert, B. Ściana, D. Pucicki, D. Radziewicz, M. Panek, B. Boratyński, A. Stafiniak, M. Ramiaczek-Krasowska, M. Tłaczała, Wrocław Univ. of Technology (Poland)

8902 0J Influence of the AP MOVPE process parameters on properties of (In, Ga)(As, N)/ GaAs heterostructures for photovoltaic applications [8902-59]

B. Ściana, D. Radziewicz, D. Pucicki, J. Serafińczuk, W. Dawidowski, K. Bielak, M. Badura, Ł. Gelczuk, M. Tłaczała, M. Lałkowska, P. Kamyczek, Wrocław Univ. of Technology

(Poland); J. Kováč, M. Florovič, A. Vincze, Slovak Univ. of Technology (Slovakia)

8902 OK On-wafer measurements and characterization of poly-si resistors for evaluation of selected CMOS manufacturing processes [8902-61]

G. Głuszko, D. Tomaszewski, J. Malesińska, K. Kucharski, Instytut Technologii Elektronowej (Poland)

$8902 \mathrm{OL}$ Modeling the current of a double-gate MOSFET with very thin active region taking into account mobility dependence on the transverse electric field [8902-66]

L. Łukasiak, B. Majkusiak, Warsaw Univ. of Technology (Poland) 
8902 OM Bipolar transistor in VESTIC technology [8902-78]

W. Kuźmicz, P. Mierzwiński, Warsaw Univ. of Technology (Poland)

8902 ON Fabrication and characterization of thin-film transistors with amorphous In-Ga-Zn-O layers [8902-84]

A. Taube, Institute of Electron Technology (Poland) and Warsaw Univ. of Technology (Poland); J. Kaczmarski, M. Ekielski, Institute of Electron Technology (Poland); D. Pucicki, Wrocław Univ. of Technology (Poland); E. Kamińska, A. Piotrowska, Institute of Electron Technology (Poland)

890200 Influence of series resistance determination on the extracted mobility in MOS transistors with Ge channel [8902-89]

J. Jasiński, L. Łukasiak, A. Jakubowski, Warsaw Univ. of Technology (Poland); C. Casteleiro,

T. E. Whall, E. H. Parker, M. Myronov, D. R. Leadley, The Univ. of Warwick (United Kingdom)

8902 OP Description of tunneling through a metal-insulator-metal junction considering Coulomb Blockade [8902-92]

D. Tanous, B. Majkusiak, Warsaw Univ. of Technology (Poland)

$89020 Q \quad$ Thin film metal oxide gas sensor array for gas detection [8902-93]

P. Gwiżdż, A. Brudnik, K. Zakrzewska, AGH Univ. of Science and Technology (Poland)

8902 OR Investigation of temperature effect on electrical characteristics of the double barrier metal-oxide-semiconductor structure [8902-97]

D. Tanous, A. Mazurak, B. Majkusiak, Warsaw Univ. of Technology (Poland)

8902 OS Investigation of current-voltage characteristics of the transistor structures with double-potential barrier DBMOS [8902-99]

A. Mazurak, D. Tanous, B. Majkusiak, Warsaw Univ. of Technology (Poland)

8902 OT Aspects of SiC diode assembly using Ag technology [8902-104]

M. Mysliwiec, Warsaw Univ. of Technology (Poland) and Institute of Electron Technology (Poland); M. Guziewicz, Institute of Electron Technology (Poland); R. Kisiel, Warsaw Univ. of Technology (Poland)

8902 OU Electrical characterization of GaN-channel MOSFETs [8902-106]

J. Jasiński, L. Łukasiak, A. Jakubowski, Warsaw Univ. of Technology (Poland); D.-K. Kim,

D.-S. Kim, S.-H. Hahm, J.-H. Lee, Kyungpook National Univ. (Korea, Republic of)

8902 OV Fabrication of nanocrystallites in the $\mathrm{SiO}_{\mathbf{x}}$ matrix applicable in microelectronics [8902-112]

T. Kolodziej, AGH Univ. of Science and Technology (Poland)

8902 OW Resistive shorts characterization in CMOS standard cells for test pattern generation [8902-117]

A. Wielgus, B. Potrykus, Warsaw Univ. of Technology (Poland)

8902 0X Nanostructures applied to bit-cell devices [8902-1 18]

A. Kołodziej, AGH Univ. of Science and Technology (Poland); L. Łukasiak, Warsaw Univ. of Technology (Poland); M. Kołodziej, AGH Univ. of Science and Technology (Poland)

8902 OY CURRENT source with controlled power supply voltage [8902-119]

J. Sikora, Lublin Univ. of Technology (Poland) 
$89020 Z$ Robustness of digital approach to mismatch compensation in analog circuits realized in nanometer technologies [8902-132]

Z. Jaworski, P. Wysokiński, Warsaw Univ. of Technology (Poland)

890210 Analysis of e-beam impact on the resist stack in e-beam lithography process [8902-133] K. Indykeiwicz, B. Paszkiewicz, Wrocław Univ. of Technology (Poland)

890211 The influence of mounting and thermal strains on defects disclose during ageing test for laser diodes for $808 \mathrm{~nm}$ and $880 \mathrm{~nm}$ bands [8902-12]

E. Dabrowska, A. Kozłowska, M. Teodorczyk, J. Zawistowska, G. Sobczak, A. Malag, Institute of Electronic Materials Technology (Poland)

890212 Design and properties of silicon charged-particle detectors developed at the Institute of Electron Technology (ITE) [8902-52]

M. Węgrzecki, J. Bar, T. Budzyński, M. Cież, P. Grabiec, Instyłut Technologii Elektronowej (Poland); R. Kozłowski, Instytut Technologii Materiałów Elektronicznych (Poland); J. Kulawik, A. Panas, Instytut Technologii Elektronowej (Poland); J. Sarnecki, Instytut Technologii Materiałów Elektronicznych (Poland); W. Słysz, D. Szmigiel, I. Węgrzecka, Instyłut Technologii Elektronowej (Poland); M. Wielunski, Helmholtz Zentrum München, GmbH (Poland); K. Witek, Instytut Technologii Elektronowej (Poland); A. Yakushev, GSI Helmholtzzentrum für Schwerionenforschung GmbH (Poland); M. Zaborowski, Instytut Technologii Elektronowej (Poland)

890213 Optoelectronic and photonic sensors of mastitis in cow milk [8902-24] M. Borecki, Warsaw Univ. of Technology (Poland) and Warsaw Univ. of Life Science (Poland); T. Niemiec, Warsaw Univ. of Life Science (Poland) and Warsaw Univ. of Technology (Poland); M. L. Korwin-Pawlowski, Univ. du Québec en Outaouais (Canada); B. Kuczyńska, Warsaw Univ. of Life Science (Poland); P. Doroz, Warsaw Univ. of Technology (Poland); K. Urbańska, M. Szmidt, Warsaw Univ. of Life Science (Poland) and Warsaw Univ. of Technology (Poland); J. Szmidt, Warsaw Univ. of Technology (Poland) and Warsaw Univ. of Life Science (Poland)

890214 Development of elliptical nanostructured gradient index microlens (Invited Paper) [8902-85]

R. Buczynski, Univ. of Warsaw (Poland) and Institute of Electronic Materials Technology (Poland); A. J. Waddie, Heriot-Watt Univ. (United Kingdom); J. Nowosielski, A. Filipkowski, Univ. of Warsaw (Poland) and Heriot-Watt Univ. (United Kingdom); D. Pysz, R. Stepien, Institute of Electronic Materials Technology (Poland); M. R. Taghizadeh, Heriot-Watt Univ. (United Kingdom)

890215 Octave spanning supercontinuum in normal dispersion photonic crystal fiber [8902-101] B. Siwicki, Univ. of Warsaw (Poland) and Institute of Electronic Materials Technology (Poland); M. Klimczak, Institute of Electronic Materials Technology (Poland); P. Skibinski, Institute of Physical Chemistry (Poland); T. Martynkien, Wrocław Univ. of Technology (Poland); D. Pysz, R. Stępien, A. Szolno, Institute of Electronic Materials Technology (Poland); C. Radzewicz, Univ. of Warsaw (Poland); R. Buczynski, Univ. of Warsaw (Poland) and Institute of Electronic Materials Technology (Poland) 
890216 Two methods of determining the birefringence of the planar waveguides [8902-113]

K. Gut, Silesian Univ. of Technology (Poland)

890217 Characterization of the optical beam emitted by high-power phase-locked arrays of diode lasers ( $P=1$ W CW) [8902-11]

G. Sobczak, Institute of Electronic Materials Technology (Poland) and Warsaw Univ. of Technology (Poland); E. Dąbrowska, M. Teodorczyk, J. Kalbarczyk, A. Malag, Institute of Electronic Materials Technology (Poland)

890218 Compact diode-side-pumped Yb:YAG slab laser operating in room temperature [8902-13] M. Kaskow, W. Zendzian, J. K. Jabczynski, J. Firak, L. Gorajek, J. Kwiatkowski, K. Kopczynski, Military Univ. of Technology (Poland)

890219 Diode pumped, q-switched Tm:YLF laser [8902-14]

L. Gorajek, Military Univ. of Technology (Poland)

$89021 \mathrm{~A}$ Three-octave spanning supercontinuum generation in a fluoride (ZBLAN) fiber [8902-27] M. Michalska, J. Swiderski, Military Univ. of Technology (Poland)

$89021 \mathrm{~B} \quad$ Pulse shape distortion in a 2-stage all-fiber Er-doped amplifier [8902-28]

M. Michalska, M. Mamajek, Military Univ. of Technology (Poland)

8902 1C Influence of construction and technology on the time stability of the neutron sensors [8902-30]

M. Stolarski, M. Węgrzecki, J. Kulawik, B. Synkiewicz, Institute of Electron Technology (Poland)

8902 1D Digital controlling system to the set of high power LEDs [8902-42]

M. Gilewski, L. Gryko, A. Zajac, Białystok Univ. of Technology (Poland)

$89021 \mathrm{E} \quad$ Light generation of DBR/F-P laser based on Raman effect in a silicon-on-insulator rib waveguide [8902-43]

A. Tyszka-Zawadzka, Warsaw Univ. of Technology (Poland); P. Szczepański, Warsaw Univ. of Technology (Poland) and National Institute of Telecommunications (Poland); M. Karpierz, A. Mossakowska-Wyszyńska, M. Bugaj, Warsaw Univ. of Technology (Poland)

$89021 \mathrm{~F}$ Determination of carrier concentration in VECSEL lasers [8902-45]

W. Jung, A. Jasik, K. Gołaszewska, E. Maciejewska, Institute of Electron Technology (Poland)

$89021 \mathrm{G}$ Optical fibers for FTTH application [8902-46]

B. Guzowski, G. Tosik, Z. Lisik, M. Bedyk, A. Kubiak, Lodz Univ. of Technology (Poland)

$89021 \mathrm{H} \quad$ Designing of Raman lasers with Bragg mirrors [8902-53]

A. Mossakowska-Wyszyńska, A. Tyszka-Zawadzka, R. Mroczyński, R. B. Beck, Warsaw Univ. of Technology (Poland); P. Szczepański, Warsaw Univ. of Technology (Poland) and National Institute of Telecommunications (Poland) 
890211 Technology of silicon charged-particle detectors developed at the Institute of Electron Technology (ITE) [8902-54]

I. Wegrzecka, A. Panas, J. Bar, T. Budzyński, P. Grabiec, Instytut Technologii Elektronowej (Poland); R. Kozłowski, J. Sarnecki, Instyłut Technologii Materiałów Elektronicznych (Poland); W. Słysz, D. Szmigiel, M. Węgrzecki, M. Zaborowski, Instyłut Technologii Elektronowej (Poland)

$89021 \mathrm{~J}$ Detection of nitric oxide in exhaled air using cavity enhanced absorption spectroscopy [8902-67]

R. Mędrzycki, J. Wojtas, B. Rutecka, Z. Bielecki, Military Univ. of Technology (Poland)

$89021 \mathrm{~K} \quad$ Selective deep wet etching of fused silica optical fibers for sensing applications [8902-71] K. Krogulski, M. Śmietana, N. Kwietniewski, K. Król, Warsaw Univ. of Technology (Poland)

$89021 \mathrm{~L}$ Development of the technology related to the selective covering of detectors surface with dielectric light-proof layer [8902-76]

H. Kłos, B. Synkiewicz, J. Bar, Institute of Electron Technology (Poland)

$89021 \mathrm{M}$ The use of photonic techniques in tunable microwave oscillators [8902-87]

K. Madziar, A. Szymańska, B. Galwas, Instytut Mikroelektroniki i Optoelektroniki (Poland)

$89021 \mathrm{~N}$ Sensing characteristics of polymer highly birefringent side-hole fiber [8902-1 16] P. Mergo, J. Klimek, K. Skorupski, Maria Curie-Sklodowska Univ. (Poland); K. Gąsior, M. Grzondko, T. Martynkien, Wrocław Univ. of Technology (Poland); G. Wójcik, A. Walewski, J. Pédzisz, J. Kopeć, Maria Curie-Sklodowska Univ. (Poland); W. Urbańczyk, Wrocław Univ. of Technology (Poland)

890210 Preparation of long-period gratings (LPGs) for biological substances detection [8902-130] A. K. Dębowska, M. Śmietana, Warsaw Univ. of Technology (Poland); E. Brzozowska, S. Górska-Fraczak, Institute of Immunology and Experimental Therapy (Poland); W. J. Bock, P. Mikulic, Univ. du Québec en Outaouais (Canada)

$89021 \mathrm{P} \quad$ Silicon nitride ( $\mathrm{SiN}_{\mathbf{x}}$ ) plasma deposition on optical fiber sensors: coating symmetry perspective [8902-136]

A. Krysiński, M. Śmietana, R. Mroczyński, N. Kwietniewski, Warsaw Univ. of Technology (Poland); W. J. Bock, P. Mikulic, Univ. du Québec en Outaouais (Canada)

$89021 Q \quad$ Application of mobile computers in a measuring system supporting examination of posture diseases (Invited Paper) [8902-25] J. Piekarski, E. Klimiec, W. Zaraska, Instytut Technologii Elektronowej (Poland)

$89021 R$ The effect of the temperature value on the accuracy of time constant measurements for the platinum voltammetry electrodes [8902-32] K. Mazur, Gdansk Univ. of Technology (Poland)

8902 is A prototype femtosecond laser system for MEMS fabrication [8902-34] K. Garasz, M. Kocik, M. Tański, R. Barbucha, Institute of Fluid-Flow Machinery (Poland); J. Mizeraczyk, Institute of Fluid-Flow Machinery (Poland) and Gdynia Maritime Univ. (Poland); M. Nejbaver, C. Radzewicz, Institute of Physical Chemistry (Poland) 
$89021 \mathrm{~T} \quad$ Properties of carbonaceous-palladium hydrogen sensor [8902-37]

A. Kamińska, S. Krawczyk, H. Wronka, E. Czerwosz, Tele and Radio Research Institute (Poland); P. Firek, J. Kalenik, J. Szmidt, Warsaw Univ. of Technology (Poland)

$89021 \mathrm{U}$ Adjustment of sensivity of ISFET-type micro- and nanosensors [8902-41] M. Zaborowski, D. Tomaszewski, P. Grabiec, Instytut Technologii Elektronowej (Poland)

$89021 \mathrm{~V}$ The ink-jet printing of microstrip lines on ferroelectric ceramic-polymer composites and its characterization in sub-THz range [8902-48]

J. Weremczuk, G. Tarapata, R. Jachowicz, Y. Yashchyshyn, K. Godziszewski, P. Bajurko, M. Syafran, E. Pawlikowska, Warsaw Univ. of Technology (Poland)

$89021 \mathrm{~W} \quad$ Fabrication and measurement of micromechanical bridge structures for mass change detection [8902-57]

M. M. Moczała, Wrocław Univ. of Technology (Poland); A. Sierakowski, R. Dobrowolski, P. Grabiec, Institute of Electron Technology (Poland); T. P. Gotszalk, Wrocław Univ. of Technology (Poland)

$89021 \mathrm{1X}$ Manufacturing, measurement and control of MEMS / NEMS electrostatically driven structures [8902-69]

M. A. Ekwińska, Institute of Electron Technology (Poland); P. Kunicki, T. Piasecki, Wrocław Univ. of Technology (Poland); P. Janus, K. Domański, T. Bieniek, P. Grabiec, Institute of Electron Technology (Poland); T. Gotszalk, Wrocław Univ. of Technology (Poland)

$89021 \mathrm{Y}$ Application of Triton surfactant adsorption on Si surface for fabrication of $45^{\circ}$ micromirrors [8902-79]

K. P. Rola, I. Zubel, Wrocław Univ. of Technology (Poland)

890212 Microcontact printing technology as a method of fabrication of patterned self-assembled monolayers for application in nanometrology [8902-91]

P. Pałetko, M. Moczała, Wrocław Univ. of Technology (Poland); P. Janus, P. Grabiec, Institute of Electron Technology (Poland); T. Gotszalk, Wrocław Univ. of Technology (Poland)

890220 Dynamic method of calibration and examination piezoresistive cantilevers [8902-128] A. Sierakowski, Institute of Electron Technology (Poland); D. Kopiec, Wrocław Univ. of Technology (Poland); M. Ekwińska, Institute of Electron Technology (Poland); T. Piasecki, Wrocław Univ. of Technology (Poland); R. Dobrowolski, M. Płuska, K. Domański, P. Grabiec, Institute of Electron Technology (Poland); T. P. Gotszalk, Wrocław Univ. of Technology (Poland)

$890221 \quad$ Numerical models of magnetic field MEMS sensors used in optoelectronic microsystems [8902-129]

J. Gołębiowski, S. Milcarz, Lodz Univ. of Technology (Poland)

\section{SESSION 4 ELECTRONIC AND PHOTONIC MATERIALS AND TECHNOLOGIES}

890222 Fluctuating phenomena in resistive materials and devices (Invited Paper) [8902-6]

A. W. Stadler, Rzeszów Univ. of Technology (Poland) 
890223 Characterization and properties of multicomponent oxide thin films with gasochromic effect [8902-8]

J. Domaradzki, K. Baniewicz, M. Mazur, D. Wojcieszak, D. Kaczmarek, Wrocław Univ. of Technology (Poland)

890224 Characterisation and application of $\mathrm{WO}_{3}$ films for electrochromic devices [8902-29]

T. Stapinski, K. Marszalek, B. Swatowska, A. Stanco, AGH Univ. of Science and Technology (Poland)

890225 Carbon footprint of electronic devices [8902-15]

M. Sloma, Warsaw Univ. of Technology (Poland) and Research and Innovation Ctr.

Pro-Akademia (Poland)

890226 Metal oxide nanostructures for gas detection [8902-22]

W. Maziarz, T. Pisarkiewicz, A. Rydosz, K. Wysocka, G. Czyrnek, AGH Univ. of Science and Technology (Poland)

890227 Influence of carbon nanoparticles on the properties of screen printed polymer composites [8902-31]

M. Jakubowska, Warsaw Univ. of Technology (Poland) and Institute of Electronic Materials Technology (Poland); K. Janeczek, Tele and Radio Research Institute (Poland); A. Młożniak, Institute of Electronic Materials Technology (Poland); G. Kozioł, A. Araźna, Tele and Radio Research Institute (Poland)

890228 Wide band antireflective coatings $\mathrm{Al}_{2} \mathrm{O}_{3} / \mathrm{HfO}_{2} / \mathrm{MgF}_{2}$ for $\mathrm{UV}$ region [8902-33] P. Winkowski, PEVIN (Poland); K. W. Marszałek, AGH Univ. of Science and Technology (Poland)

890229 Signal detection and processing system for three-dimensional imaging of nonconductive surfaces in SEM [8902-36]

W. Slówko, M. Kryszłof, Wrocław Univ. of Technology (Poland)

8902 2A Formation of ultrathin silicon layers by PECVD and their modification for nanoelectronic and nanophotonic applications [8902-39]

K. Ber, R. B. Beck, Warsaw Univ. of Technology (Poland)

8902 2B Nematic liquid crystals in inverted microstrip structures [8902-38]

J. Piotrowski, Warsaw Univ. of Technology (Poland); J. Parka, Warsaw Univ. of Technology

(Poland) and Military Univ. of Technology (Poland); E. Nowinowski-Kruszelnicki, Military Univ. of Technology (Poland)

8902 2C Properties of hydrogen sensitive C-Pd films obtained by PVD/CVD method [8902-49] E. Kowalska, M. Kozłowski, A. Kamińska, J. Radomska, H. Wronka, E. Czerwosz, Tele and Radio Research Institute (Poland); K. Sobczak, Institute of Physics (Poland)

8902 2D The influence of MOVPE process parameters on the buffer resistivity used in AIGaN/GaN heterostructures [8902-56]

T. Szymański, M. Wośko, B. Paszkiewicz, R. Paszkiewicz, Wrocław Univ. of Technology (Poland)

8902 2E Liquid crystal tunable microwave band stop filters [8902-62]

J. Skulski, A. Szymańska, Warsaw Univ. of Technology (Poland) 
$89022 \mathrm{G}$ Influence of rapid thermal annealing on optical properties of (In, Ga)(As, N)/GaAs quantum wells [8902-64]

W. Dawidowski, B. Ściana, M. Latkowska, D. Radziewicz, D. Pucicki, K. Bielak, M. Badura,

M. Tłaczała, Wrocław Univ. of Technology (Poland)

8902 2H Characterization of Diamond-like Carbon (DLC) films deposited by RF ICP PECVD method [8902-65]

W. Oleszkiewicz, W. Kijaszek, J. Gryglewicz, A. Zakrzewski, K. Gajewski, D. Kopiec,

P. Kamyczek, E. Popko, M. Tłaczała, Wrocław Univ. of Technology (Poland)

8902 2l Behavior of tensioactive compounds in the solutions for silicon anisotropic etching [8902-73]

I. Zubel, K. Rola, J. Zalewska, Wrocław Univ. of Technology (Poland)

8902 2J Investigation of ITO layers for application as transparent contacts in flexible photovoltaic cell structures [8902-74]

K. Znajdek, M. Sibiński, Lodz Univ. of Technology (Poland)

8902 2K Low-resistance contact layers on the basis of polymer composites containing silver nanoparticles dedicated to semiconductor devices [8902-75]

J. Kalbarczyk, A. Młożniak, K. Krzyżak, M. Teodorczyk, Institute of Electronic Materials Technology (Poland)

$89022 \mathrm{~L}$ Silicon nanowires reliability and robustness investigation using AFM-based techniques [8902-80]

T. Bieniek, G. Janczyk, P. Janus, P. Grabiec, M. Nieprzecki, Instytut Technologii Elektronowej (Poland); G. Wielgoszewski, M. Moczała, T. Gołszalk, Wrocław Univ. of Technology (Poland); E. Buitrago, M. F.-B. Badia, A. M. Ionescu, EPFL (Switzerland)

$89022 \mathrm{M}$ Characterization of thin $\mathrm{Gd}_{2} \mathrm{O}_{3}$ magnetron sputtered layers [8902-81]

J. Gryglewicz, Wrocław Univ. of Technology (Poland); P. Firek, J. Jaśiński, R. Mroczyński, J. Szmidt, Warsaw Univ. of Technology (Poland)

8902 2N In-Ga-Zn-O amorphous thin films for transparent electronics [8902-86] J. Kaczmarski, Institute of Electron Technology (Poland); A. Taube, Institute of Electron Technology (Poland) and Warsaw Univ. of Technology (Poland); E. Dynowska, Insitute of Electron Technology (Poland) and Institute of Physics (Poland); J. Dyczewski, Institute of Physics (Poland); M. Ekielski, Insitute of Electron Technology (Poland); D. Pucicki, Wrocław Univ. of Technology (Poland); E. Kamińska, A. Piotrowska, Institute of Electron Technology (Poland)

890220 Reactive impulse plasma ablation deposited barium titanate thin films on silicon [8902-88] A. Werbowy, P. Firek, N. Kwietniewski, A. Olszyna, Warsaw Univ. of Technology (Poland)

8902 2P Influence of selected environmental factors on electrical and physical properties of polymer-semiconductor layers [8902-107]

M. Mroczkowski, J. Kalenik, J. Szmidt, Warsaw Univ. of Technology (Poland)

$89022 \mathrm{C}$ Characterisation of AP-MOVPE grown (Ga, In)(N, As) structures by Raman spectroscopy [8902-1 14]

M. Badura, B. Ściana, D. Radziewicz, D. Pucicki, K. Bielak, W. Dawidowski, P. Kamyczek, E. Płaczek-Popko, M. Tłaczała, Wrocław Univ. of Technology (Poland) 
8902 2R Characterizations of GalnNAs/GaAs quantum wells [8902-115]

K. Bielak, D. Pucicki, B. Ściana, D. Radziewicz, W. Dawidowski, M. Badura, R. Kudrawiec,

J. Serafińczuk, M. Tłaczała, Wrocław Univ. of Technology (Poland)

8902 2S Structural analysis of epitaxial NbTiN films [8902-120]

M. Guziewicz, A. Laszcz, Institute of Electron Technology (Poland); J. Z. Domagala, Institute of Electron Technology (Poland) and Institute of Physics (Poland); K. Golaszewska, J. Ratajczak, R. Kruszka, M. Juchniewicz, A. Czerwinski, W. Slysz, Institute of Electron Technology (Poland)

$89022 \mathrm{~T}$ Synthesis and characterization of polymer composite base on $\mathrm{RE}^{3+}: \mathrm{Al}_{2} \mathrm{O}_{3}$ nanopowders doped by rare earth metals for application in optoelectronics [8902-123]

P. Polis, A. Jastrzębska, J. Jureczko, A. Jusza, R. Piramidowicz, K. Anders, A. Olszyna,

A. Kunicki, W. Fabianowski, Warsaw Univ. of Technology (Poland)

Author Index 


\section{Conference Committee}

\section{Conference Chairs}

Paweł Szczepański, Warsaw University of Technology (Poland) Wiesław Woliński, Warsaw University of Technology (Poland) Maciej Bugajski, Institute of Electron Technology (Poland) Andrzej Dziedzic, Wrocław University of Technology (Poland) Zygmunt Łuczyński, Institute of Electronic Materials Technology (Poland)

Zygmunt Mierczyk, Military University of Technology (Poland)

Tadeusz Pisarkiewicz, AGH University of Science and Technology (Poland)

Wiesław Woliński, Warsaw University of Technology (Poland)

\section{Scientific Committee}

Romuald B. Beck, Warsaw University of Technology (Poland) Zbigniew Bielecki, Military University of Technology (Poland) Michał Borecki, Warsaw University of Technology (Poland) Zbigniew Brzózka, Warsaw University of Technology (Poland) Piotr Dumania, Institute of Electron Technology (Poland) Jan Dziuban, Wrocław University of Technology (Poland) Jan Felba, Wrocław University of Technology (Poland) Marek Godlewski, Institute of Physics (Poland) Leszek Golonka, Wrocław University of Technology (Poland) Teodor P. Gotszalk, Wrocław University of Technology (Poland) Piotr Grabiec, Institute of Electron Technology (Poland) Ryszard Jachowicz, Warsaw University of Technology (Poland) Andrzej Jakubowski, Warsaw University of Technology (Poland) Małgorzata Jakubowska, Warsaw University of Technology (Poland) Włodzimierz Janke, Koszalin University of Technology (Poland) Danuta Kaczmarek, Wrocław University of Technology (Poland) Ryszard Kisiel, Warsaw University of Technology (Poland) Stanisław Kłosowicz, Military University of Technology (Poland) Andrzej Kolek, Rzeszow University of Technology (Poland) Andrzej Kołodziej, AGH University of Science and Technology (Poland)

Krzysztof Kopczyński, Military University of Technology (Poland) Bogdan Kosmowski, Gdansk University of Technology (Poland) Jerzy Krupka, Warsaw University of Technology (Poland) Zbigniew Lisik, Lodz University of Technology (Poland) Lidia Kukasiak, Warsaw University of Technology (Poland) Bogdan Majkusiak, Warsaw University of Technology (Poland) 
Michał Malinowski, Warsaw University of Technology (Poland) Włodzimierz Nakwaski, Lodz University of Technology (Poland) Andrzej Napieralski, Lodz University of Technology (Poland) Regina Paszkiewicz, Wrocław University of Technology (Poland) Janusz Parka, Warsaw University of Technology (Poland)

Andrzej Pfitzner, Warsaw University of Technology (Poland)

Dorota Pijanowska-Nałęcz, Institute of Biocybernetics and Biomedical Engineering (Poland)

Witold A. Pleskacz, Warsaw University of Technology (Poland) Witold Posadowski, Wrocław University of Technology (Poland) Tadeusz Pustelny, Silesian University of Technology (Poland) Jacek Radojewski, Wrocław University of Technology (Poland) Ryszard S. Romaniuk, Warsaw University of Technology (Poland) Tomasz Stapiński, AGH University of Science and Technology (Poland) Tomasz Stobiecki, AGH University of Science and Technology (Poland) Włodzimierz Strupiński, Institute of Electronic Materials Technology

(Poland)

Jan Szmidt, Warsaw University of Technology (Poland) Jacek Szuber, Silesian University of Technology (Poland) Marek Tłaczała, Wrocław University of Technology (Poland) Jerzy Woźnicki, Warsaw University of Technology (Poland) Jerzy Żuk, Maria Curie Skłodowska University (Poland)

International Committee

Jerzy Rużyło, The Pennsylvania State University (United States)

Tomasz Skotnicki, STMicroelectronics (France)

Andrzej Strójwąs, Carnegie Mellon University (United States)

Local organizing Committee

Ryszard Piramidowicz, Chairman, Warsaw University of Technology (Poland)

Krzysztof Anders, Warsaw University of Technology (Poland)

Anna Jusza, Warsaw University of Technology (Poland)

Krzysztof Madziar, Warsaw University of Technology (Poland)

Agnieszka Mossakowska-Wyszyńska, Warsaw University of Technology (Poland)

Robert Mroczyński, Warsaw University of Technology (Poland) Hanna Sater, Warsaw University of Technology (Poland) Mariusz Sochacki, Warsaw University of Technology (Poland)

Anna Tyszka-Zawadzka, Warsaw University of Technology

Katrin Welikow, Warsaw University of Technology

Piotr Witoński, Warsaw University of Technology

Agnieszka Zaręba, Warsaw University of Technology 


\section{Session Chairs}

1 Microelectronics and Nanoelectronics

Andrzej Napieralski, Lodz University of Technology (Poland)

Lidia Kukasiak, Warsaw University of Technology (Poland)

Andrzej Dziedzic, Wrocław University of Technology (Poland)

Andrzej Pfitzner, Warsaw University of Technology (Poland)

2 Photonics

Zygmunt Mierczyk, Military University of Technology (Poland)

Tadeusz Pustelny, Silesian University of Technology (Poland)

Ryszard S. Romaniuk, Warsaw University of Technology (Poland)

Marek Godlewski, Institute of Physics (Poland)

3 Microsystems

Jan Dziuban, Wrocław University of Technology (Poland)

Piotr Grabiec, Institute of Electron Technology (Poland)

Ryszard Jachowicz, Warsaw University of Technology (Poland)

Teodor P. Gotszalk, Wrocław University of Technology (Poland)

4 Electronic and Photonic Materials and Technologies

Marek Tłaczała, Wrocław University of Technology (Poland)

Jan Szmidt, Warsaw University of Technology (Poland)

Danuta Kaczmarek, Wrocław University of Technology (Poland)

Jan Felba, Wrocław University of Technology (Poland) 
Proc. of SPIE Vol. $8902890201-16$

Downloaded From: https://www.spiedigitallibrary.org/conference-proceedings-of-spie on 26 Apr 2023 Terms of Use: https://www.spiedigitallibrary.org/terms-of-use 


\section{Introduction}

The ELTE 2013 Conference on Electron Technology was the eleventh meeting in a periodical series that deals with advances in state-of-the-art electron technology in Poland. Historically this series of Conferences has evolved since 1980 due to the activity of the national research community active in electronic and photonic materials and components research. This community is located at government laboratories, universities, and recently at business research institutions. At the end of the 1970s and early eighties, representatives of three electron technology research institutions (Warsaw University of Technology, Wrocław University and AGH-University of Mining and Metallurgy in Kraków) decided to start a cyclic national meeting devoted solely to electronic materials and technologies. Since then, the conference has been organized rotationally between these strong research centers. The original aim of the conference, as defined more than three decades ago, was to build a solid forum for presentation and exchange of national achievements covering broadly understood electron technology.

The first Conference on Electron Technology ELTE' 80 was organized in Wrocław (conference opening ceremony and plenary papers) and in Karpacz, on 24-27 September 1980, and was hosted by the Institute of Electron Technology, Wrocław University of Technology. The meeting gathered then more than 200 researchers, showing the strength of this branch of science and technology in Poland. The proceedings were published as a separate book in the series Research Works of Wrocław University of Technology, in the Conference subseries as Vol 24 (4) in 1980. The volume contains 2 keynote papers, 25 plenary papers and 156 contributed papers. The conference works were divided into the following four topical sessions: Technology of High Vacuum; Technology of Electron, Ion and Photon Beams; Optoelectronics; and Hybrid Microelectronics. The Chairman of the ELTE' 80 Conference Scientific Committee was Prof. Bohdan Paszkowski.

Electron Technology II - ELTE'84 was organized by the Institute of Electron Technology (later renamed to Institute of Microelectronics and Optoelectronics), Warsaw University of Technology, in Rynia near Warsaw on 13-16 June 1984. Similar to the first conference, a volume of proceedings was published containing abstracts of plenaries and contributed papers. The volume contains 348 paper abstracts. During the conference, four keynote plenary papers were presented on hot topics of electron technology: microelectronics industry in Poland, physical confinements and technological barriers in MOS VLSI development, material engineering and future of microelectronics, and surface research of electronic materials by electron and ion methods. The contributed papers were divided into the following topical sections: Microelectronics, with four section papers and 59 contributed papers; Optoelectronics, with 5 section papers and 71 contributed papers; High Vacuum, with 6 section papers and 99 contributed papers; 
Electronic Materials, with 5 section papers and 44 contributed papers; Passive Electronic Components, with 4 section papers and 47 contributed papers. Full texts of some plenary papers were published in the SEP (Association of Polish Electrical Engineers) Technical Journal Elektronika No. 6, 7, and 8, 1984. The Honorary Chairman of the ELTE'84 Conference Scientific Committee was Prof. Janusz Groszkowski, the Chairman was Prof. Alfred Świt.

Electron Technology III - ELTE' 87 was organized by the Institute of Physics of Adam Mickiewicz University in Poznań.

Electron Technology IV - ELTE'90 was organized again by the Institute of Electron Technology, Wrocław University of Technology.

Electron Technology $\vee$ - ELTE'94 was organized by the Institute of Microelectronics and Optoelectronics, Warsaw University of Technology.

Electron Technology VI - ELTE'97 was organized by the Chair of Electronics, AGH-Academy of Mining and Metallurgy in Kraków.

Electron Technology VII - ELTE' 2000 was organized by the Institute of Microsystems Technology (renamed from Institute of Electron Technology), Wrocław University of Technology.

Electron Technology VIII - ELTE'2004 was organized by the Institute of Microelectronics and Optoelectronics, Warsaw University of Technology. There were presented 10 plenary papers, 39 section papers, and around 150 contributed papers. Conference papers were divided into six topical sessions: Electronic Materials, Micorelectronics, Nanoelectronics, Vacuum Science and Technology, Microsystems, and Magnetoelectronics. Honorary Chairman of the Conference was Prof. Witold Rosiński, and Chairman was Prof. Wiesław Woliński.

Electron Technology IX - ELTE'2007 was organized by the Chair of Electronics, AGH-Academy of Mining and Metallurgy in Kraków on 4-7 September 2007. The Conference was associated with the $55^{\text {th }}$ Anniversary of the Faculty of Electrotechnics, Automation, Informatics and Electronics of the AGH University. Conference Proceedings were published as a volume of abstracts and in technical journals: Measurement Science and Technology, Vacuum and Elektronika. The conference was traditionally accompanied by a technical exhibit. Prof. Tadeusz Pisarkiewicz was Chairman of the Scientific Committee of ELTE' 2007.

The Jubilee Electron Technology X - ELTE'2010 - was organized by Wrocław University of Technology together with IMAPS-CPMT Poland 2010 Conference, on 22-25 September. Topical scope of the conference was divided into four parts: Microelectronics and Nanoelectronics, Photonics, Microsystems, and Electronic Materials. The scope of the IMPS-CMPT Poland 2010 Conference included: thin 
and thick film technologies; thin and thick film sensors; modeling, design and simulation of multichip structures, components and circuits; modern technologies and applications of multichip modules; electrical, optical, mechanical and thermal characterization of film structures, components and circuits; packaging in electronics, photonics and Microsystems; quality and reliability of film structures and packaging processes. During ELTE 2010 there were presented 4 keynote papers, 48 plenary session papers and 146 contributed papers during poster sessions. The conference was accompanied by technical exhibit. Prof. Andrzej Dziedzic was a Chairman of the Scientific Committee of ELTE 2010.

Electron Technology XI - ELTE' 2013 was organized by the Institute of Microelectronics and Optoelectronics, Warsaw University of Technology. ELTE' 2013 gathered around 270 participants. There were presented 9 plenary papers, 50 oral papers and 165 poster papers. Scientific Committee of ELTE' 2013 awarded 12 students and young researchers with the Best Presentation Award funded by the Conference and by the SPIE. The Conference Chairman was prof.Paweł Szczepański.

The topics and sessions of Electron Technology XI - ELTE 2013 were as follows:

1. Photonics:

- Semiconductor light sources

- Detectors and photovoltaic

- New materials for optical applications

- Passive optoelectronics devices

- Nonlinear optical materials

2. Microsystems

- Electrical, mechanical and thermal modeling and design of Microsystems

- Design and fabrication of MEMS and MOEMS systems

- Smart sensing structures

- Lab-on-chip systems

- Micro- and nanobiosystems

3. Materials Technology for Optoelectronics and Electronics:

- Fabrication and full characterization of optoelectronics and electronics materials

- Applying nanotechnology for manufacturing photonics as well as electronics materials

- Bio- and nanomaterials for photonic, electronic and microelectronic systems

- Advanced methods for characterization of materials and electronics devices

- Hybrid and printed circuits boards technology 
4. Microelectronics and Nonoelectronics

- Electrical, mechanical and thermal design and fabrication of semiconductor devices and integrated circuits

- Simulation of technological processes

- Micro- and nano technology (with using electron, ion and molecular beams)

- Spintronic and magnetoelectronic

- Characterization and diagnostic of technological processes of semiconductor devices and integrated circuits

- Packaging of photonics and microelectronics devices

The Conference ELTE 2013 provided material for two volumes of proceedings. One of them was published in Polish (a volume of abstracts of all conference presentations) and one in English (SPIE Proceedings). Additionally, a CD-ROM was added to the volume of abstracts containing extended abstracts of all papers. The editors of this volume present the full texts of around 100 chosen and reviewed articles by authors affiliated primarily with university and governmentbased laboratories.

The conference chairs and editors would like to thank personally the authors and conference contributors who made this book possible. A number of devoted reviewers from the conference Scientific Committee contributed a lot to the betterment of this book. Special thanks are also due to SPIE for supporting the conference by undertaking the publication of this proceedings volume. The Conference Committee announces with pleasure that the next meeting on Electron Technology ELTE 2016 is scheduled to be organized by the AGH University of Science and Technology in Kraków in 2016, under the chairmanship of Prof. Tadeusz Pisarkiewicz.

\section{Paweł Szczepański Ryszard Kisiel Ryszard S. Romaniuk}

